\title{
Manajemen Pelayanan Keamanan Masyarakat Berbasis IT Guna Menjaga Stabilitas Keamanan Dan Ketertiban Masyarakat (Program Panic Button on hand Polres Malang Kota)
}

\author{
Decky Hendarsono \\ decky.hendarsono-2016@pasca.unair.ac.id \\ Program Studi Magister Kajian Ilmu Kepolisian Sekolah Pascasarjana \\ Uiversitas Airlangga \\ Jln. Airlangga No.4-6 Surabaya
}

\begin{abstract}
The increasing number of crimes forces the need for security to be the main thing and is an important requirement for humans to run daily activities. This study aims to analyze and describe efforts to optimize community service programs in the field of IT-based community service in Malang City Police. The research method used is qualitative, with interview data collection techniques and observation. The results of the study were discussed using two concepts, namely the first question regarding management of IT-based community services in Malang City Police, where those measured using the concept of POAC (planning, organizing, controling, actuating). Meanwhile, the second question discussed about efforts to optimize the management of public security services in the field of IT-based community security uses the $4 \mathrm{~m}$ concept (man, money, material and method).
\end{abstract}

Keywords: Crime; Panic Button; Technology; Police.

\begin{abstract}
Meningkatnya jumlah kriminalitas memaksa kebutuhan akan rasa aman menjadi sesuatu yang utama dan merupakan kebutuhan yang penting bagi manusia dalam menjalakan aktivitas sehari-hari. Penelitian ini bertujuan untuk menganalisis dan mendeskripsikan upaya optimalisasi program pelayanan masyarakat di bidang kamtibmas yang berbasis IT pada Polres Malang Kota. Metode penelitian yang digunakan adalah kualitatif, dengan teknik pengumpulan data wawancara dan observasi. Hasil penelitian dibahas menggunakan dua konsep yaitu pertanyaan pertama mengenai manajemen pelayanan masyarakat berbasis IT pada Polres Malang Kota, dimana yang diukur menggunakan konsep POAC (planning, organizing, controling, actuating). Sementara, pertanyaan kedua dibahas mengenai upaya optimalisasi manajemen pelayanan keamanan masyarakat di bidang kamtibmas yang berbasis IT menggunakan konsep 4m (man, money,material and method).
\end{abstract}

Kata Kunci: Kriminalitas;Panic Button; Teknologi; Polisi.

\section{A. Pendahuluan}

Indonesia terus mengalami peningkatan jumlah penduduk setiap tahunnya dengan laju pertumbuhan 1,49 persen/tahun. Peningkatan penduduk yang cepat mengakibatkan berbagai aktivitas ekonomi dan sosial yang bertambah pula. Kebutuhan masyarakat juga semakin beragam. Semakin tingginya permintaan barang dan jasa yang dibutuhkan, tidak sebanding dengan kekuatan untuk memenuhi, seperti terbatasnya lapangan pekerjaan sebagai sumber mencari nafkah. 
Tidak adanya lapangan pekerjaan yang tersedia mengakibatkan banyaknya masyarakat yang menganggur sehingga tidak dapat memenuhi kebutuhan hidupnya.

Meningkatnya jumlah pengangguran di Indonesia menimbulkan berbagai macam masalah sosial di masyarakat, salah satunya kriminalitas. Kriminalitas merupakan tindakan kejahatan yang melanggar hukum. Meningkatnya jumlah kriminalitas memaksa kebutuhan akan rasa aman menjadi sesuatu yang utama dan merupakan kebutuhan yang penting bagi manusia dalam menjalakan aktivitas sehari-hari. Semakin tinggi angka kriminalitas menunjukkan semakin banyak tindak kejahatan pada masyarakat yang merupakan indikasi bahwa masyarakat merasa semakin tidak aman.

Tabel 1.

\section{Jumlah Tindak Pidana Menurut Kepolisian Daerah di Pulau Jawa}

\begin{tabular}{|l|r|r|r|}
\hline \multirow{2}{*}{ Provinsi } & \multicolumn{3}{|c|}{ Jumlah } \\
\cline { 2 - 4 } & \multicolumn{1}{|c|}{2015} & \multicolumn{1}{c|}{2016} & \multicolumn{1}{c|}{2017} \\
\hline Metro Jaya & 49.498 & 44.298 & 44.461 \\
\hline Jawa Barat & 24.843 & 27.058 & 27.805 \\
\hline Banten & 4.259 & 5.741 & 5.002 \\
\hline Jawa Tengah & 14.859 & 15.993 & 15.958 \\
\hline DI Yogyakarta & 6.727 & 7.135 & 9.692 \\
\hline Jawa Timur & 16.913 & 14.102 & 35.437 \\
\hline Jumlah & 117.099 & 114.327 & 138.355 \\
\hline
\end{tabular}

Sumber: BPS 2019 (Biro Pengendalian Operasional, Mabes Polri)

Pulau Jawa merupakan penyumbang jumlah kejahatan tertinggi kedua (pada tahun 2017) di Indonesia. Begitu juga dengan Jawa Timur yang memiliki jumlah kejahatan tertinggi di Pulau Jawa. Kenaikan yang cukup signifikan terjadi pada tahun 2017. Hal ini menunjukkan bahwa adanya pihak kepolisian yang bertugas untuk menjaga keamanan, namun jumlah kejahatan yang terjadi sangat tinggi dan terus meningkat, sedangkan kriminalitas merupakan masalah yang serius, terutama di daerah perkotaan.

Tabel 2.

Persentase Jumlah Tindak Pidana yang Diselesaikan Menurut Kabupaten/Kota di Jawa Timur

\begin{tabular}{|l|c|c|c|c|}
\hline \multirow{2}{*}{\multicolumn{1}{|c|}{ Kota }} & \multicolumn{3}{|c|}{ Persentase } & \\
\cline { 2 - 5 } Kota Kediri & 2013 & 2014 & 2015 & Rata- \\
\hline Kota Blitar & 66,35 & 60,48 & 53,08 & 59,97 \\
\hline
\end{tabular}




\begin{tabular}{|l|l|l|l|l|}
\hline Kota Malang & 25,72 & 32,48 & 32,51 & 30,24 \\
\hline Kota Probolinggo & 61,86 & 67,58 & 65,91 & 65,12 \\
\hline Kota Pasuruan & 58,58 & 51,00 & 63,41 & 57,66 \\
\hline Kota Mojokerto & 70,00 & 65,51 & 65,17 & 66,89 \\
\hline Kota Madiun & 89,63 & 67,42 & 65,81 & 74,29 \\
\hline Kota Surabaya & 60,32 & 67,02 & 88,84 & 72,06 \\
\hline Kota Batu & 45,89 & 47,79 & 66,67 & 53,45 \\
\hline
\end{tabular}

Sumber: BPS Provinsi Jawa Timur, data diolah

Tabel 2. menunjukkan bahwa kasus kejahatan yang terjadi di daerah perkotaan Jawa Timur tidak dapat diselesaikan secara maksimal. Salah satunya adalah Kota Malang yang memiliki persentase penyelesaian tindak kejahatan terkecil diantara Kota lain di Jawa Timur. Tingginya tingkat kriminalitas memaksa pihak kepolisian Kota Malang dalam meningkatkan kualitas pelayanan yang terkait dengan tindak kriminalitas yang terjadi melalui inovasi pelayanan.

Inovasi pelayanan yang dibuat oleh Kapolres Malang Kota AKBP Singgamata, S.I.K.,M.H., dalam pelayanan penanganan laporan kriminalitas adalah Panic Button on Hand (PBOH), yang mencoba memformulasikan pelayanan perangkat pusat Komunikasi, Koordinasi, Komando dan Pengendalian serta Informasi (K3I) Polres Malang Kota yang telah dimiliki dan berupaya memanfaatkan teknologi komunikasi terbaru yakni handphone jenis android. PBOH merupakan aplikasi tombol darurat yang dapat digunakan saat seseorang dalam keadaan bahaya atau sedang melihat tindak kriminalitas di lingkungannya.

Aplikasi ini memudahkan masyarakat dalam memberikan laporan tanpa perlu datang ke kantor polisi terdekat. Selain itu memudahkan pihak kepolisian dalam menangani tindak kriminalitas karena mengetahui dengan jelas lokasi kejahatan. Pentingnya penanganan laporan kriminalitas membuat Kementerian Pendayagunaan Aparatur Negara dan Reformasi Birokrasi (Kemenpan-RB) sangat mengapresiasi inovasi pelayanan $\mathrm{PBOH}$ ini, yaitu dengan memberikan penghargaan TOP 35

Inovasi Pelayanan Publik kepada Polres Malang Kota melalui inovasi PBOH.

Inovasi $\mathrm{PBOH}$ juga dapat dimanfaatkan oleh warga luar Kota Malang, namun dengan ketentuan harus berada di area Kota Malang. Ini cara paling mudah untuk warga yang membutuhkan polisi. Antusiasme masyarakat dengan adanya $\mathrm{PBOH}$ ini sangat besar, yang ditunjukkan dengan jumlah pengunduh sebanyak 6.548 orang. Namun, hal ini tidak sebanding dengan banyaknya jumlah laporan kriminal yang masuk ke Polres Malang Kota dengan menggunakan $\mathrm{PBOH}$. 
Tabel 3.

Jumlah Laporan yang Masuk ke Polres Malang Kota Tahun 2016-2017

\begin{tabular}{|l|l|c|l|}
\hline \multicolumn{1}{|c|}{ Cara Penyampaian } & Jumlah & Kejahata & Persentase \\
\hline $\begin{array}{l}\text { Melalui aplikasi } \\
\text { Panic Button on }\end{array}$ & 568 & 15 & 2,64 \\
\hline $\begin{array}{l}\text { Tanpa menggunakan } \\
\text { Panic Button on }\end{array}$ & 5.131 & 4.903 & 95,56 \\
\hline
\end{tabular}

Sumber: Humas Polres Malang Kota, data diolah

Tabel 3. menunjukkan bahwa keseluruhan laporan yang masuk ke Polres Malang Kota selama tahun 2015 sampai tahun 2016 lebih banyak dilaporkan tanpa melalui aplikasi PBOH, yaitu sebesar 4.903 laporan kriminalitas. Terlihat perbedaan yang sangat jauh karena hanya 15 laporan kriminalitas saja yang masuk melalui PBOH. Hal ini dikarenakan banyak kemungkinan penyebabnya, yaitu masih banyak masyarakat yang belum mengerti dan mengetahui, serta masih banyak juga masyarakat yang tidak bias mengakses aplikasi karena tidak memiliki smartphone untuk mengunduh aplikasi PBOH, sehingga mereka masih melaporkan tindak kejahatan dengan langsung datang ke Kantor Polisi terdekat atau melalui telefon.

Berdasarkan latar belakang telah dijelaskan bahwa Kepolisian Kota Malang telah memiliki aplikasi khusus dalam meningkatkan pelayanan penanganan laporan kriminalitas. Kepercayaan masyarakat terus terjawab seiring dengan peningkatan pelayanan polisi saat dibutuhkan. PBOH Polres Malang Kota juga menjadi daya tarik bagi kota lain untuk menerapkan inovasi pelayanan yang sama. Namun, masih terdapat banyak kendala dalam pelaksanaannya. Hal tersebut yang menjadi ketertarikan dalam melakukan penelitian terkait dengan inovasi pelayanan oleh Polres Malang Kota dalam menangani tindak kriminalitas di Kota Malang yang dilaporkan langsung oleh masyarakat, serta mengetahui faktor-faktor penghambat yang mempengaruhi penerapannya.

Melalui berbagai penjelasan tersebut, tujuan dari penelitian ini adalah untuk mendeskripsikan dan menganalisis pelayanan melalui aplikasi Panic Button on Hand sebagai inovasi dalam penanganan laporan kriminalitas di Kota Malang. Selain itu untuk mengetahui faktor-faktor yang menghambat penerapan inovasi Panic Button on Hand yang dilakukan oleh Polres Malang Kota. 


\section{B. Metode}

Tipe penelitian yang digunakan dalam penelitian ini adalah jenis deskriptif kualitatif. Format deskriptif kualitatif menganut paham fenomenologis yaitu mengkaji penampakan atau fenomena yang mana antara fenomena dan kesadaran terisolasi satu sama lain melainkan selalu berhubungan secara dialektis. Tujuannya adalah untuk menggambarkan, meringkas berbagai kondisi, berbagai situasi atau berbagai fenomena realitas sosial yang ada di masyarakat menjadi objek penelitian dan berupaya menarik realitas tersebut ke permukaan sebagai suatu ciri, karakter, sifat, model, tanda atau gambaran tentang kondisi, situasi ataupun fenomena tertentu.

\section{Pembahasan}

Peran dan tugas pokok Polri bertujuan untuk mewujudkan keamanan dalam negeri yang meliputi terpeliharanya keamanan dan ketertiban masyarakat, tertib dan tegaknya hukum, terselenggaranya perlindungan, pengayoman, dan pelayanan kepada masyarakat dan menjunjung tinggi hak asasi manusia sebagaimana terlihat pada rumusan Pasal 14 Undangundang Nomor 2 Tahun 2002 tentang Kepolisian RI.

Secara umum situasi keamanan di wilayah Kota Malang sangat ditentukan oleh kondisi demografi dan keadaan ekonomi serta sosial budaya. adanya perkembangan infrastruktur yang mempengaruhi pertumbuhan ekonomi di Kota Malang, hal ini juga dapat berpotensi meningkatnya ancaman keamanan dan ketertiban masyarakat.

Menyadari berbagai kendala dan permasalahan yang terjadi di tengah heterogenitas masyarakat kota Malang yang kritis dan peduli terhadap dinamika operasional Polri, serta dengan memberdayakan peluang yang dimiliki baik di internal Polres maupun eksternal kota Malang, maka Polres Kota Malang mencoba memformulasikan pelayanan masyarakat dengan perangkat pusat Komunikasi, Koordinasi, Komando dan Pengendalian serta Informasi (K3I) Polres Malang Kota yang telah dimiliki dan berupaya memanfaatkan teknologi komunikasi terbaru dan trendy (banyak dimiliki/dipakai kalangan masyarakat luas) yakni handphone jenis android, dengan formulasi tersebut diharapkan walaupun biaya minimal namun dapat terakses di seluruh lapisan masyarakat khususnya kota Malang. dikarenakan adanya ke khawatiran aparat kepolisian tidak memiliki kekuatan dan kemampuan memadai dalam melaksanakan anggungjawabnya pada waktu yang bersamaan, sedangkan masyarakat apabila memerlukan bantuan Polisi masih harus datang secara fisik ke kantor Polisi sehingga tidak tertutup kemungkinan adanya masyarakat yang 
tidak terlayani secara proporsional terutama apabila masyarakat dihadapkan pada situasi yang benar-benar membutuhkan

${ }^{1}$ Conny R Semiawan. Metode Penelitian Kualitatif Jenis, Karakteristik dan Keunggulannya. Jakarta: Grafindo. 2010, hal. 72.

panic button on hand 


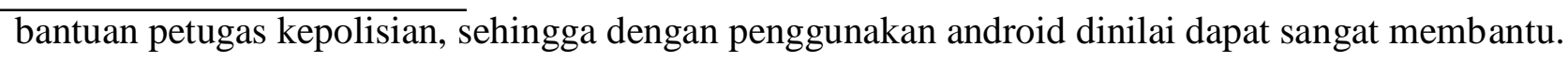
Problematika kamtibmas di wilayah hukum Polres Kota Malang adalah terkait meningkatnya kejahatan di wilayah hukum Polsek Lowokwaru,dimana merupakan wilayah terdapat perguruan tinggi dan perumahan serta indekos mahasiswa. Kejahatan yang paling sering terjadi di Kota Malang adalah pencurian kendaraan bermotor. Faktor apa yang berpengaruh terhadap perubahan sosial. Paling tidak terdapat enam faktor yang berpengaruh terhadap perubahan sosial;

1. Penyebaran informasi, meliputi pengaruh dan mekanisme media dalam menyampaikan pesanpesan ataupun gagasan (pemikiran).

2. Modal, antara lain SDM ataupun modal finansial.

3. Teknologi, suatu unsur dan sekaligus faktor yang cepat berubah sesusai dengan perkembangan ilmu pengetahuan.

4. Ideologi atau agama, bagaimana agama atau ideologi tertentu berpengaruh terhadap proses perubahan social.

5. Birokrasi, terutama berkaitan dengan berbagai kebijakan pemerintahan tertentu dalam membangun kekuasaannya.

6. Agen atau aktor. Hal ini secara umum termasuk dalam modal SDM, tetapi secara spesifik yang dimaksudkan adalah inisiatif-inisiatif individual dalam "mencari” kehidupan yang lebih baik.

Dalam kaitannya dengan perubahan sosial di Kota Malang terkait dengan perkembangan SDM, ilmu pengetahuan dan teknologi. Ketiga hal tersebut yang menyebabkan dan memicu peningkatan kejahatan di Kota Malang. 
Tabel 4

Data Kasus Kriminal di Kota Malang Tahun 2017 dan 2018

\begin{tabular}{|c|l|c|c|c|c|c|c|}
\hline \multirow{2}{*}{ No } & \multirow{2}{*}{ Jenis Kejahatan } & \multicolumn{3}{|c|}{ Tahun 2017 } & \multicolumn{3}{c|}{ Tahun 2018 } \\
\cline { 3 - 8 } & & L & S & \multicolumn{2}{c|}{ \% } & \multicolumn{3}{c|}{ S } & \% \\
\hline I. & KEJAHATAN KONVENSIONAL & \multicolumn{4}{|c|}{} \\
\hline 1 & Pembunuhan & - & - & - & - & - & - \\
\hline 2 & Anirat & 96 & 81 & 84 & 14 & 17 & 121 \\
\hline 3 & Penculikan & 2 & - & - & 1 & 1 & 100 \\
\hline 4 & Curas & 16 & 15 & 94 & 15 & 12 & 80 \\
\hline 5 & Curat & 116 & 103 & 89 & 188 & 91 & 48 \\
\hline 6 & Curanmor & 379 & 158 & 42 & 584 & 88 & 15 \\
\hline 7 & Perkosaan & 2 & 3 & 150 & 1 & 1 & 100 \\
\hline 8 & Kebakaran & 11 & 9 & 82 & 33 & 12 & 36 \\
\hline 9 & Upal & - & - & - & 2 & 3 & 150 \\
\hline 10 & Bawa lari gadis & 1 & 1 & 100 & - & - & - \\
\hline 11 & Sajam & 10 & 16 & 160 & 3 & 4 & 133 \\
\hline 12 & Pemerasan & 20 & 16 & 80 & 5 & 3 & 60 \\
\hline 13 & Perjudian & 53 & 53 & 100 & 28 & 58 & 207 \\
\hline 14 & Perzinahan & 4 & 6 & 150 & - & - & - \\
\hline 15 & Penadahan & - & 24 & - & - & 2 & - \\
\hline 16 & Pengrusakan & 19 & 16 & 84 & 5 & 4 & 80 \\
\hline 17 & Penipuan & 180 & 89 & 49 & 50 & 25 & 50 \\
\hline 18 & Penggelapan & 103 & 87 & 84 & 29 & 22 & 76 \\
\hline 19 & Pengroyokan & 66 & 57 & 86 & 22 & 32 & 145 \\
\hline 20 & Curi biasa & 140 & 112 & 80 & 112 & 107 & 95 \\
\hline 21 & Cabul & 7 & 9 & 128 & 1 & 2 & 200 \\
\hline 22 & Aniring & 27 & 16 & 59 & 34 & 55 & 162 \\
\hline 23 & Serobot tanah & 2 & 2 & 100 & - & - & - \\
\hline 24 & Penghinaan & 3 & 3 & 100 & 2 & 1 & 50 \\
\hline 25 & Palsu surat & 15 & 6 & 40 & 1 & - & 0 \\
\hline 26 & CVD & - & - & - & - & - & - \\
& bajakan/HAKI & & & & & & \\
\hline 27 & Pornografi & - & - & - & - & - & - \\
\hline 28 & $\begin{array}{l}\text { Mati } \\
\text { mendadak/ }\end{array}$ & 3 & 2 & 67 & 33 & 20 & 61 \\
\hline 29 & UU pemukiman & - & - & - & - & - & - \\
\hline 30 & KDRT & 82 & 46 & 56 & 4 & 2 & 50 \\
\hline 31 & Perc Pencurian & 3 & 3 & 100 & 5 & 2 & 40 \\
\hline 32 & Fidusia & - & - & - & 6 & 3 & 50 \\
\hline & & & & & & \\
\hline
\end{tabular}




\begin{tabular}{|c|c|c|c|c|c|c|c|}
\hline \multirow[t]{2}{*}{ No } & \multirow{2}{*}{ Jenis Kejahatan } & \multicolumn{3}{|c|}{ Tahun 2017} & \multicolumn{3}{|c|}{ Tahun 2018} \\
\hline & & $\mathbf{L}$ & $\mathbf{S}$ & $\%$ & $\mathbf{L}$ & $\mathbf{S}$ & $\%$ \\
\hline 33 & Ciri dalam keluarga & - & - & - & - & - & - \\
\hline 34 & Buang bayi & - & - & - & - & - & - \\
\hline 35 & Ket palsu & - & - & - & - & - & - \\
\hline 36 & UU Jahi & - & - & - & - & - & - \\
\hline 37 & Lindung anak & 41 & 23 & 56 & 1 & 5 & 500 \\
\hline 38 & $\begin{array}{l}\text { Perbuatan } \\
\text { tidak }\end{array}$ & 14 & 11 & 79 & - & - & - \\
\hline 39 & Kenakalan remaja & - & - & - & - & - & - \\
\hline 40 & Perampasan & - & - & - & 4 & - & 0 \\
\hline 41 & $\begin{array}{l}\text { Perl } \\
\text { konsumen/ }\end{array}$ & - & - & - & - & - & - \\
\hline 42 & Pergi tanpa pamit & 33 & 25 & - & 29 & 11 & 38 \\
\hline 43 & Bunuh diri & - & - & - & - & - & - \\
\hline 44 & Gelap dalam & - & - & - & - & - & - \\
\hline 45 & Penyuapan & - & - & - & - & - & - \\
\hline 46 & UU Perhutani & - & - & - & - & - & - \\
\hline 47 & $\begin{array}{l}\text { Kejahatan } \\
\text { terhadap nyawa }\end{array}$ & - & - & - & - & - & - \\
\hline 48 & Penodaan agama & - & - & - & - & - & - \\
\hline 49 & $\begin{array}{l}\text { Kejahatan } \\
\text { terhadap }\end{array}$ & - & - & - & - & - & - \\
\hline 50 & Kecelakaan senpi & - & - & - & - & - & - \\
\hline 51 & Lain-lain & 476 & 243 & 51 & 25 & 88 & 352 \\
\hline II. & \multicolumn{7}{|c|}{ KEJAHATAN TRANSNASIONAL } \\
\hline 52 & Narkoba & 92 & 100 & 92 & 162 & 164 & 101 \\
\hline 53 & Money laundry & - & - & - & - & - & - \\
\hline 54 & Teror & - & - & - & - & - & - \\
\hline 55 & Traficking & - & - & - & - & - & - \\
\hline 56 & Cyber crime & - & - & - & - & - & - \\
\hline 57 & Selundup senpi & - & - & - & - & - & - \\
\hline 58 & Trans ekonomi & - & - & - & - & - & - \\
\hline 59 & Perampokan & - & - & - & - & - & - \\
\hline III & \multicolumn{7}{|c|}{ KEJAHATAN TERHADAP KEKAYAAN NEGARA } \\
\hline 60 & Ilegal logging & - & - & - & - & - & - \\
\hline 61 & Penambangan & - & - & - & - & - & - \\
\hline 62 & Korupsi & 2 & 1 & 50 & - & - & - \\
\hline 63 & \begin{tabular}{|l|l}
$\mathrm{BBM}$ & \\
\end{tabular} & - & - & & & & \\
\hline IV & \multicolumn{7}{|c|}{ KEJAHATAN BERIMPLIKASI KONTIJENSI } \\
\hline 64 & Sparatis & - & - & - & - & - & - \\
\hline 65 & Konflik etnis & - & - & - & - & - & - \\
\hline 66 & Kerusuhan massa & - & - & - & - & - & - \\
\hline & Jumlah & 2.089 & 1.456 & 70 & $\begin{array}{c}128 \\
2\end{array}$ & 712 & 56 \\
\hline
\end{tabular}


untuk operator panic button on hand sangat dibutuhkan seperti alat

\section{Tabel 5}

\section{Jumlah Kejahatan di Kota Malang tahun 2016, 2017 dan 2018}

\begin{tabular}{|c|c|c|}
\hline Tahun & Crime Total & Crime Clearence \\
\hline $\mathbf{2 0 1 6}$ & 4.689 & 1.689 \\
\hline $\mathbf{2 0 1 7}$ & 3.328 & 1.623 \\
\hline $\mathbf{2 0 1 8}$ & 1.584 & 583 \\
\hline
\end{tabular}

Sumber: Polres Malang Kota

Data dalam tabel di atas menunjukkan bahwa terjadi penurunan angka kejahatan di wilayah hukum Polres Malang Kota. Pada tahun 2016, jumlah kejahatan di wilayah hukum Polres Malang Kota adalah 4.689 kasus dengan crime clearence berjumlah 1.689. Namun pada tahun 2017, terjadi penurunan angka kejahatan menjadi 3.328 dengan crime clearence berjumlah 1.623. Pada tahun 2018, juga terlihat penurunan angka kejahatan menjadi 1.584 dengan crime clearence berjumlah 583.

Maka bila dikaitkan antara hasil temuan dengan teori yang ada maka dapat disimpulkan manajemen pelayanan masyarakat berbasis IT pada Polres Malang Kota yang diukur menggunakan konsep POAC (planning, organizing, controling, actuating), yaitu Planning: Pada program pelayanan berbasis IT yang ada di Polres Malang Kota ini sudah hampir 5 tahun berjalan. Hal tersebut menunjukkan bahwa perencanaan yang dibuat oleh pimpinan (Kapolres) terdahulu sudah terimplementasi dengan baik pada perencanaan jangka menengahnya. Organizing: Pada kajian penelitian ini Panic Button on Hand (PBOH) sudah dalam memiliki tatanan organisasi dalam naungan Polres Malang kota. Controling: Pada penerapan pelayanan kemanan masyarakat. Ruangan pengendalian pelayanan Panic Button on Hand berada di ruang Makota Command Center (MCC) berdampingan Panic Button on Hand disediakan ruangan tersendiri di Polres Malang Kotadengan tujuan untuk dapat melayani secara optimal kepada kebutuhan dengan ruang SPKT Polres Malang Kota dalam satu pintu masuk utama terletat di sayap kanan bangunan induk Polres Malang Kota lantai dasar. Actuating: Dalam penerapan manajemen pelayanan berbasis IT yaitu panic button on hand fungsi actuating sudah terlaksana. Telihat pada terselesaikannya kasus.

Malang Kota, dimana dibahas dengan konsep 4m (man, money,material and method). Man: Polres Malang Kota melakukan pelatihan untuk program panic button on hand yang biasa dilakukan sebanyak 3 kali dalam setahun. Material: kebutuhan untuk operator panic button on hand sangat dibutuhkan seperti alat pelacak, sehingga manajemen pelayanan keamanan masayarakat dapat dilakukan dengan maksimal. Hal ini untuk menghindari laporan palsu. Money: biaya untuk membangun program panic button on hand ini relatif tidak ada karena semua fasilitas sudah tersedia. Method: metode yang digunakan adalah pelaporan melalui aplikasi buatan yang langsung menyambungkan pada petugas kepolisian. Dalam hal ini, pelayanan dilaksanakan oleh petugas MCC terintegrasi dengan seluruh piket fungsi tingkat Polres dan Polsek jajaran, secara struktural di bawah kendali Kabagops dan dalam pelaksanaan tugas sehari-hari dikoordinasikan oleh Kasubbag Dalops dan Pa Siaga. 
D. Kesimpupuperator panic button on hand sangat dibutuhkan seperti alat

1. Manajemen pelayanan masyarakat berbasis IT pada Polres Malang Kota, dimana yang diukur menggunakan konsep POAC (planning, organizing, controling, actuating), yaitu Planning: Pada program pelayanan berbasis IT yang ada di Polres Malang Kota ini sudah hampir 5 tahun berjalan. Hal tersebut menunjukkan bahwa perencanaan yang dibuat oleh pimpinan (Kapolres) terdahulu sudah terimplementasi dengan baik pada perencanaan jangka menengahnya. Organizing: Pada kajian penelitian ini Panic Button on Hand (PBOH) sudah dalam memiliki tatanan organisasi dalam naungan Polres Malang kota. Controling: Pada penerapan pelayanan Panic Button on Hand disediakan ruangan tersendiri di Polres Malang Kota dengan tujuan untuk dapat melayani secara optimal kepada kebutuhan kemanan masyarakat. Ruangan pengendalian pelayanan Panic Button on Hand berada di ruang Makota Command Center (MCC) berdampingan dengan ruang SPKT Polres Malang Kota dalam satu pintu masuk utama terletat di sayap kanan bangunan induk Polres Malang Kota lantai dasar. Actuating: Dalam penerapan manajemen pelayanan berbasis IT yaitu panic button on hand fungsi actuating sudah terlaksana. Telihat pada terselesaikannya kasus.

2. Upaya optimalisasi manajemen pelayanan keamanan masyarakat di bidang kamtibmas yang berbasis IT dimana dibahas dengan konsep 4m (man, money,material and method). Man: Polres Malang Kota melakukan pelatihan untuk program panic button on hand yang biasa dilakukan sebanyak 3 kali dalam setahun. Material: kebutuhan pelacak, sehingga manajemen pelayanan keamanan masayarakat dapat dilakukan dengan maksimal. Hal ini untuk menghindari laporan palsu. Money: biaya untuk membangun program panic button on hand ini relatif tidak ada karena semua fasilitas sudah tersedia. Method: metode yang digunakan adalah pelaporan melalui aplikasi buatan yang langsung menyambungkan pada petugas kepolisian. Dalam hal ini, pelayanan dilaksanakan oleh petugas MCC terintegrasi dengan seluruh piket fungsi tingkat Polres dan Polsek jajaran, secara struktural di bawah kendali Kabagops dan dalam pelaksanaan tugas sehari-hari dikoordinasikan oleh Kasubbag Dalops dan Pa Siaga.

\section{Bibliography}

Buku

Kango, Andries, Media dan Perubahan Sosial Budaya, Farabi, Volume

12 Nomor 1 Juni, hal. 20-34, 2015.

Semiawan, Conny R. Metode Penelitian Kualitatif Jenis, Karakteristik dan Keunggulannya. Jakarta: Grafindo. 2010. 